WOMEN OF THE CATACOMBS 
A volume in the NIU Series in

Slavic, East European, and Eurasian Studies

Edited by Christine D. Worobec

For a list of books in the series, visit our website at cornellpress.cornell.edu. 


\title{
WOMEN OF THE CATACOMBS
}

\author{
Memoirs of the Underground \\ Orthodox Church in Stalin's Russia
}

\section{EDITED AND TRANSLATED BY WALLACE L. DANIEL} FOREWORD BY ROY R. ROBSON Preface by ARChPRIEST AleKsandr Men 
Original Russian edition, Katakomby XX veka: Vospominaniia [Catacombs of the Twentieth Century: Memoirs]. Copyright (C) Fond imeni Aleksandra Menia, 2001

English-language translation, foreword, and editor's introduction copyright (C) 2021 by Cornell University

Illustrations courtesy of the Aleksandr Men Foundation

All rights reserved. Except for brief quotations in a review, this book, or parts thereof, must not be reproduced in any form without permission in writing from the publisher. For information, address Cornell University Press, Sage House, 512 East State Street, Ithaca, New York 14850. Visit our website at cornellpress.cornell.edu.

First published 2021 by Cornell University Press

Library of Congress Cataloging-in-Publication Data

Names: Daniel, Wallace L., editor, translator. | Robson, Roy R., writer of foreword. | Men', Aleksandr, 1935-1990, writer of preface. | Vasilevskaia, V. Ia. (Vera Iakovlevna). Katakomby XX veka.

Title: Women of the catacombs : memoirs of the underground Orthodox Church in Stalin's Russia / edited and translated by Wallace L. Daniel, foreword by Roy R. Robson, preface by Archpriest Aleksandr Men.

Description: Ithaca [New York] : Northern Illinois University Press, an imprint of Cornell University Press, 2021. | Series: NIU series in Slavic, East European, and Eurasian Studies | Translation of selections from Vera Iakovlevna Vasilevskaia's Katakomby XX veka. | Includes bibliographical references and index.

Identifiers: LCCN 2020016283 (print) | LCCN 2020016284 (ebook) | ISBN 9781501753657 (hardcover) | ISBN 9781501754401 (paperback) | ISBN 9781501754050 (ebook) | ISBN 9781501754067 (pdf)

Subjects: LCSH: Russkaia pravoslavnaia tserkov'—Soviet Union-Biography. | Christian martyrs-Soviet UnionBiography. | Persecution—Soviet Union-History. | Soviet Union-Church history.

Classification: LCC BX595 .W66 2021 (print) | LCC BX595 (ebook) | DDC 289.1092/52 [B]—dc23

LC record available at https:/ / lccn.loc.gov/ 2020016283

LC ebook record available at https: / / lccn.loc.gov/2020016284

Cover photo: Elena Tsuperfein (Men) and Vera Vasilevskaia, in the 1920s. Courtesy Fond imeni Aleksandra Menia. 
To my grandchildren-Sparrow, Eli, Jasper, and River-who represent the future, and to the Russian women who have kept alive memories of the catacomb church community 
